\title{
COST-EFFECTIVENESS OF SPRINKLER IRRIGATION OF CHOSEN EARLY CULTIVARS OF POTATO GROWN ON VERY LIGHT SOIL IN CENTRAL POLAND
}

Roman Rolbiecki $^{1}$, Magdalena Rolbiecka ${ }^{2}$, Stanislaw Rolbiecki ${ }^{1}$, Barbara Jagosz ${ }^{3}$, Ariel Langowski ${ }^{1}$

${ }^{1}$ University of Science and Technology, Poland; ${ }^{2}$ University of Gdansk, Poland; ${ }^{3}$ University of Agriculture in Krakow, Poland

rolbs@utp.edu.pl,rolbiesia@gmail.com,b.jagosz@ogr.ur.krakow.pl, ariellangowski@gmail.com

\begin{abstract}
The present paper concerns the results of long-term experiments on overhead irrigation of chosen medium early potato cultivars, carried out on a very light soil in the vicinity of Bydgoszcz (Central Poland). This region of Poland is recognized as the area of the lowest precipitation and the highest water deficits during the vegetation period. The investigation confirmed that the use of sprinkler irrigation under such soil-climatic conditions contributed to a very high multiyear productivity, which ranged from 43 to $191 \%$, depending on the cultivar. Increases in potato tuber yields caused by sprinkler irrigation were inversely proportional to rainfall during the vegetation period. The highest yield increases were obtained in dry years, whereas the lowest increases in the yields were noted in wet years. To estimate the economic efficiency of sprinkler irrigation the method of calculation of the increase in direct surplus was used. Economic results of sprinkler irrigation are dependent on the value of produce increase and assumed sprinkler irrigation costs. Total annual cost of sprinkler irrigation per 1 ha decreased with the increase of irrigated area. The highest values of the direct surplus were obtained for the cultivar Albina. The most profitable was sprinkler irrigation of potato in dry years.
\end{abstract}

Keywords: potato, cost-effectiveness, irrigation, very light soil.

\section{Introduction}

Potato is one of the most important cultivated crops in Poland. The potato growing area decreases. For example, in 2000 it amounted to 1 million 251 thousand ha. In 2010, it was only 388 thousand ha. It is estimated that in 2018 the area of potato cultivation amounted to approx. 300,000 ha and was less by about $9 \%$ than the area in 2017 [1]. Potato is a plant with high water requirements [2]. Its water needs, depending on the age of cultivars, fluctuate in the central Poland from 250 to $450 \mathrm{~mm}$ in the growing season, which means precipitation shortages in medium years between $35-65 \mathrm{~mm}$, and in dry ones from 105 to $155 \mathrm{~mm}$ [2-6].

The literature indicates that high economic effects, expressed in the amount of the direct surplus obtained, can be achieved primarily in the irrigation of berry plants and ground vegetables and - from root crops - potatoes [7;8]. Especially irrigation of potatoes intended for processing, due to the high price of the raw material produced (chips, fries), can bring very beneficial economic results [7].

The aim of the present study was an attempt to calculate the cost-effectiveness of potato sprinkler irrigation in the central Poland. This part of Poland is characterized by the enhanced water requirements of field crops [9].

\section{Materials and methods}

The work uses the results of strict long-term (1986-2013) experience with sprinkling irrigation of potato on light soils maintained at the Department of Land Reclamation and Agrometeorology, University of Science and Technology in Bydgoszcz. The potato irrigation control was carried out according to atmospheric precipitation - using the Grabarczyk's method [10].

In order to characterize the precipitation conditions of the studied period, the recommended in the world Standardized Precipitation Index (SPI) was used [11]. SPI was calculated by the following formula (1):

$$
S P I=\frac{f(P)-\mu}{\sigma},
$$

where $f(P)$ - transformed sum of precipitation in the period under consideration;

$\mu$ - average value of normalized historical precipitation;

$\sigma-$ average standard deviation of the normalized historical rainfall.

The years were considered to be: average at $S P I$ values within -0.99 to +0.99 , dry when the $S P I$ index was lower than -1.0 and wet at SPI higher than +1.0 . 
The economic efficiency of sprinkling irrigation was assessed on the basis of the calculation of the direct surplus increment (2) [12]:

$$
\Delta D=\Delta P-(K d+\Delta K r)
$$

where $\Delta D$ - increase of direct surplus, EUR $\cdot \mathrm{ha}^{-1}$;

$\Delta P$ - value of additional production obtained through the use of irrigation, EUR $\cdot \mathrm{ha}^{-1}$;

$K d$ - irrigation costs, EUR $\cdot \mathrm{ha}^{-1}$;

$\Delta K r$ - additional direct costs related to obtaining additional production, EUR $\cdot \mathrm{ha}^{-1}$.

To rate the economic efficiency of irrigation the method of direct surplus increment was used. It was obtained as a result of this procedure, which was calculated by subtracting the cost of irrigation and the increase in direct costs from the increase in the production value. As an increase in the value of production the ratio of the irrigation production effects and the average purchase price were assumed. The calculations were based on the data from the Institute of Agricultural Economics and Food Economy - National Research Institute [1] - average wholesale price of potato bulbs from 2018 was $18,8 \mathrm{EUR} \cdot \mathrm{dt}^{-1}$. In the analysis, four variants of irrigated areas were adopted: 1, 5, 10, 20 ha. Data on irrigation installation costs and subsequent irrigation costs were obtained from Łukomet and Milex companies $[6 ; 7 ; 13 ; 14]$. The economic efficiency of sprinkler irrigation was estimated, and for the purposes of the calculation the assumptions were made: the 15-year period of use of the irrigation installation (depreciation rate was assumed at $6.67 \%$ ), interest rate on capital at the level of $5 \%$, and costs of materials and repairs at the level of $2 \%$ of the investment costs. It was assumed that in the irrigation installations pumps with a combustion engine were used and the price of fuels was 1.28 EUR $\cdot \mathrm{dm}^{-3}$. It was assumed that the increase in direct costs - caused by the yield increase due to sprinkling - amounts to $30 \%$ of the value of the additional production obtained $[7 ; 12]$. For comparative purposes, the calculation does not consider the labour costs and water costs, assuming that it comes from its own surface intake. The results of the calculation are presented in EURO, taking the exchange rate from 31 December $2018(1 \mathrm{EUR}=4.3 \mathrm{PLN})$.

\section{Results and discussion}

\section{Production effects of potato sprinkler irrigation}

Irrigation significantly increased the commercial yields of potato tubers (Table 1). The average yield increase for the tested potato cultivars under the influence of sprinkling was $12.4 \mathrm{t} \cdot \mathrm{ha}^{-1}$ that is $91 \%$. The highest absolute yield increase $\left(16.9 \mathrm{t} \cdot \mathrm{ha}^{-1}\right)$ and WUE $\left(226 \mathrm{~kg} \cdot \mathrm{ha}^{-1} \cdot \mathrm{mm}^{-1}\right)$ were noted in the cultivar Albina. In turn, the largest relative yield increases - due to the low yields in the control conditions, i.e. no sprinkler irrigation - were found in the cultivars Lotos, Jaśmin and Orlik. Similarly differentiated reaction of individual cultivars of potatoes for sprinkling irrigation has already been reported earlier in better soil conditions and other regions of Poland also by other authors $[2 ; 15 ; 16]$.

Table 1

Production results of sprinkler irrigation of potato as dependent on cultivar

\begin{tabular}{|c|c|c|c|c|c|}
\hline \multirow[b]{2}{*}{ Cultivar } & \multicolumn{2}{|c|}{ Tuber yield, $t \cdot h^{-1}$} & \multicolumn{2}{|c|}{ Yield increase } & \multirow{2}{*}{$\begin{array}{c}\text { Water use } \\
\text { efficiency } \\
(\mathrm{WUE}), \\
\mathrm{kg} \cdot \mathbf{h a}^{-1} \cdot \mathbf{m m}^{-1}\end{array}$} \\
\hline & $\begin{array}{c}\text { without } \\
\text { irrigation } \\
(\mathrm{O}-\text { control })\end{array}$ & $\begin{array}{l}\text { with } \\
\text { irrigation } \\
\text { (W) }\end{array}$ & $t \cdot h a^{-1}$ & $\%$ & \\
\hline Albina & $20.6 a^{*}$ & $37.5 \mathrm{~b}$ & 16.9 & 82 & 226 \\
\hline Bila & $19.8 \mathrm{a}$ & $28.9 \mathrm{~b}$ & 9.1 & 43 & 152 \\
\hline Drop & $16.3 \mathrm{a}$ & $27.3 \mathrm{~b}$ & 11.0 & 67 & 111 \\
\hline Jaśmin & $9.6 \mathrm{a}$ & $22.6 \mathrm{~b}$ & 13.0 & 135 & 109 \\
\hline Lotos & $7.8 \mathrm{a}$ & $22.7 \mathrm{~b}$ & 14.9 & 191 & 124 \\
\hline Orlik & $8.0 \mathrm{a}$ & $17.5 \mathrm{a}$ & 9.5 & 119 & 80 \\
\hline Avg. value & $13.7 \mathrm{a}$ & $26.1 \mathrm{~b}$ & 12.4 & 91 & 134 \\
\hline
\end{tabular}

*Significant difference between the tuber yields obtained on control $(\mathrm{O})$ and irrigated plots $(\mathrm{W})$ for the same cultivar (Tukey test) 
The production effects of irrigation depended on atmospheric precipitation during the growing season of potato (Table 2). The largest yield increases $\left(22 \mathrm{t} \cdot \mathrm{ha}^{-1}\right.$, i.e. $\left.278 \%\right)$ were recorded in dry years $(S P I$ lower than -1.0$)$. Lower increases $\left(10 \mathrm{t} \cdot \mathrm{ha}^{-1}\right.$, i.e. $\left.69 \%\right)$ were found in average years $(S P I$ from -0.99 to +0.99$)$, and the lowest $\left(7.2 \mathrm{t} \cdot \mathrm{ha}^{-1}\right.$, i.e. $\left.33 \%\right)$ - in wet $(S P I$ higher than +1.0$)$. These results are confirmed by earlier findings of other authors, however, referring to other regions, better soils and other cultivars $[2 ; 15 ; 16]$.

Table 2

Production results of sprinkler irrigation of potato as dependent on type of year

\begin{tabular}{|c|c|c|c|c|c|c|}
\hline \multirow[b]{2}{*}{ Year } & \multirow[b]{2}{*}{$\begin{array}{c}\text { Rainfall*, } \\
\text { mm }\end{array}$} & \multirow{2}{*}{$\begin{array}{c}\text { Seasonal } \\
\text { irrigation } \\
\text { water rate } \\
\text { mm }\end{array}$} & \multicolumn{2}{|c|}{ Tuber yield, $\mathbf{t} \cdot h^{-1}$} & \multicolumn{2}{|c|}{ Yield increase } \\
\hline & & & $\begin{array}{c}\text { without } \\
\text { irrigation } \\
\text { (control - O) }\end{array}$ & $\begin{array}{l}\text { with } \\
\text { irrigation } \\
\text { (W) }\end{array}$ & $t \cdot h a^{-1}$ & $\%$ \\
\hline Wet & $130-190$ & 70 & 21.7 & 28.9 & 7.2 & 33 \\
\hline Mean & $90-170$ & 80 & 14.5 & 24.5 & 10.0 & 69 \\
\hline Dry & $80-100$ & 180 & 7.9 & 29.9 & 22.0 & 278 \\
\hline Avg. value & $100-150$ & 110 & 14.7 & 27.8 & 13.1 & 89 \\
\hline
\end{tabular}

*Rainfall - rainfall amount in the flowering - haulm drying period.

**Water rate - mean seasonal water rate.

\section{Cost-effectiveness of sprinkler irrigation of potato}

Potato irrigation was profitable - the average growth of direct surplus $(\Delta D)$ for 6 tested cultivars, depending on the size of the irrigated area, ranged from $523 \mathrm{EUR} \cdot \mathrm{ha}^{-1}$ ( $\left.1 \mathrm{ha}\right)$ to $1414 \mathrm{EUR} \cdot \mathrm{ha}^{-1}$ (20 ha) (Table 3). The most profitable was irrigation of the cultivar Albin ( $\Delta D$ ranged from 1077 to $\left.1968 \mathrm{EUR} \cdot \mathrm{ha}^{-1}\right)$ and cultivar Lotos $\left(\Delta D\right.$ ranged within $\left.853-1744 \mathrm{EUR} \cdot \mathrm{ha}^{-1}\right)$. Irrigation was also highly profitable in the case of the cultivars Drop and Jaśmin ( $\Delta D$ ranged from 338 to 1493 EUR $\left.\cdot h^{-1}\right)$. Irrigation was the least viable for the cultivar Bila $\left(\Delta D\right.$ ranged from 88 to $\left.979 \mathrm{EUR} \cdot \mathrm{ha}^{-1}\right)$.

Table 3

Cost-effectiveness of sprinkler irrigation of chosen potato cultivars

\begin{tabular}{|c|c|c|c|c|c|c|c|}
\hline \multirow{2}{*}{ Cultivar } & \multirow{2}{*}{$\begin{array}{c}\Delta P, \\
\text { EUR }^{\prime} \mathbf{h a}^{-1}\end{array}$} & \multirow{2}{*}{$\begin{array}{c}\Delta K r, \\
\text { EUR }^{-h^{-1}}\end{array}$} & \multicolumn{4}{|c|}{$\Delta D$, EUR $^{\prime} \cdot \mathbf{h a}^{-1}$} & \multirow{2}{*}{$\boldsymbol{R}$} \\
\hline & & & 1 ha & 5 ha & 10 ha & 20 ha & \\
\hline Albina & 3127 & 938 & 1077 & 1881 & 1933 & 1968 & 1 \\
\hline Bila & 1714 & 514 & 88 & 892 & 944 & 979 & 6 \\
\hline Drop & 2072 & 622 & 338 & 1142 & 1194 & 1229 & 4 \\
\hline Jaśmin & 2449 & 735 & 602 & 1406 & 1458 & 1493 & 3 \\
\hline Lotos & 2807 & 842 & 853 & 1657 & 1709 & 1744 & 2 \\
\hline Orlik & 1790 & 537 & 141 & 945 & 997 & 1032 & 5 \\
\hline Avg. value & 2336 & 701 & 523 & 1327 & 1379 & 1414 & - \\
\hline
\end{tabular}

$\Delta$ - marketable yield increase influenced by irrigation, $\mathrm{t} \cdot \mathrm{ha}^{-1} ; \Delta D$-increase of agricultural income, EUR $\cdot \mathrm{ha}^{-1} ; \Delta P$ - value of additional produce, resulting by irrigation, EUR $\cdot \mathrm{ha}^{-1}$;

$\Delta K r$ - increase in agricultural costs resulting from additional produce, EUR $\cdot \mathrm{ha}^{-1} ; R$ - ranking

Potato irrigation was the most profitable in dry years (Table 4). Increase of direct surplus $(\Delta D)$, depending on the size of the irrigated area, in the dry years ranged from 1716 to $2607 \mathrm{EUR} \cdot \mathrm{ha}^{-1}$. In the average years, the profitability of irrigation measured by the increase in direct surplus increased from $207 \mathrm{EUR} \cdot \mathrm{ha}^{-1}$ (area of $1 \mathrm{ha}$ ) to $1098 \mathrm{EUR} \cdot \mathrm{ha}^{-1}$ (20 ha). In the wet years, irrigation was unprofitable on plantations with the smallest area considered ( $1 \mathrm{ha})$, and on the largest one (20 ha) - a direct surplus of $728 \mathrm{EUR} \cdot \mathrm{ha}^{-1}$ was stated. In general, the profitability of irrigation increased with the increase of the irrigated area. This was due to the fact that the total annual sprinkler irrigation costs $(K d)$ - including depreciation, interest on capital, costs of repairs and materials, water costs, and fuel costs - decreased with the increase in the irrigated area in the range from $1112 \mathrm{EUR} \cdot \mathrm{ha}^{-1}$ (area of $1 \mathrm{ha}$ ) to $221 \mathrm{EUR} \cdot \mathrm{ha}^{-1}$ (area of 20 ha). 
Cost-effectiveness of sprinkler irrigation of potato as dependent on type of year

\begin{tabular}{|c|c|c|c|c|c|c|c|}
\hline \multirow[t]{2}{*}{ Year } & \multirow{2}{*}{$\begin{array}{c}\Delta P, \\
\text { EUR }^{-h^{-1}}{ }^{-1}\end{array}$} & \multirow{2}{*}{$\begin{array}{c}\Delta K r, \\
\text { EUR }^{\prime} \text { ha }^{-1}\end{array}$} & \multicolumn{4}{|c|}{$\Delta D$, EUR$^{\prime} \cdot \mathbf{h a}^{-1}$} & \multirow[t]{2}{*}{$R$} \\
\hline & & & 1 ha & 5 ha & $10 \mathrm{ha}$ & 20 ha & \\
\hline Wet & 1356 & 407 & -163 & 641 & 693 & 728 & 3 \\
\hline Mean & 1884 & 565 & 207 & 1011 & 1063 & 1098 & 2 \\
\hline Dry & 4145 & 1243 & 1716 & 2520 & 2572 & 2607 & 1 \\
\hline Avg. value & 2468 & 740 & 616 & 1420 & 1472 & 1507 & - \\
\hline
\end{tabular}

Explanations - see Table 3

The economic analysis proved that the usage of sprinkler irrigation was cost-effective, which confirmed the previous opinions and reports concerning sprinkler irrigation of other field and vegetable crops and cultivars [7;17-21].

According to many authors [22-26], the climate changes taking place (among others the increase in temperature) will lead to an increase in the water needs of plants, including potatoes, in the near future [27]. Therefore, it is necessary to undertake a number of adaptation activities, for example, drip irrigation, which significance - along with the increase in adverse climate change - will probably increase [28;29]. In the analysis of Kledzik [30] applying of drip irrigation was economically unjustified in moist years and on average in the multi-year period. In the years with dry and average precipitation conditions the direct surplus was positive (except for irrigation of the lowest area $-1 \mathrm{ha}$ ). On the other hand, it is worth mentioning that tuber yields of potato cultivated under irrigation conditions are characterized by good quality [31;32].

\section{Conclusions}

1. Sprinkling irrigation increased the commercial yields of tubers of all medium-early cultivars of the potato tested. Of the six tested cultivars of early potatoes, the best response to irrigation was demonstrated by 'Albina'.

2. The production effects of sprinkling potatoes were negatively correlated with the precipitation of the growing season. The highest yield increases were recorded in dry years, lower in average, and the lowest - in wet ones.

3. The most profitable was irrigation of the cultivar Albina.

4. The profitability of irrigation increased with the increase of the irrigated area.

5. Potato irrigation was the most profitable in dry years, less profitability of this treatment was found in average years, and the lowest - in wet years.

\section{References}

[1] IERiGŻ-PIB. Ziemniaków jest znacząco mniej niż w poprzednim sezonie. 2018. [on line] [8.03.2019]. Available at: http://www.sadyogrody.pl. (In Polish)

[2] Nowak L. Potrzeby wodne roślin okopowych. In: J. Dzieżyc (Editor). Potrzeby wodne roślin uprawnych, Warszawa: PWN, 1989, pp. 85-118. (In Polish)

[3] Nowak L., Podstawka-Chmielewska E., Rojek S. Water demand and sprinkling irrigation effects of potatoe and sugar beet in Poland. Proceedings of $1^{\text {st }}$ Poland-Israel Conference „Water requirements and irrigation effects of plants cultivated in arid and semiarid climates", December 15-16, 1997, Tel-Aviv, Israel, vol. II, pp. 71-75.

[4] Trybała M. Water resources and their possible use in Polish agriculture. Proceedings of $1^{\text {st }}$ Poland-Israel Conference „Water requirements and irrigation effects of plants cultivated in arid and semiarid climates", December 5-16, 1997, Tel-Aviv, Israel, vol. II, pp. 63-70.

[5] Rzekanowski C., Rolbiecki S., Rolbiecki R. Yields of potatoes grown on light soils under irrigation and nitrogen fertilization. Acta Horticulturae, vol. 729, 2007, pp. 347-351.

[6] Kledzik R., Kropkowski M., Rzekanowski C., Żarski J. Economic evaluation of the efficiency of irrigation in selected crops. Infrastructure and Ecology of Rural Areas, vol. II(1), 2015, pp. 291303.

[7] Jankowiak J., Rzekanowski C. Economic effects of irrigation. In: S. Karczmarczyk \& L. Nowak (Editors). Plant irrigation, Poznań: PWRiL, 2006, pp. 461-479. 
[8] Rolbiecki R., Rolbiecka M., Rolbiecki S., Jagosz B., Michalcewicz-Kaniowska M., Zajdel M. 2018. Cost-effectiveness of postharvest drip irrigation of chosen North-American cultivars of asparagus grown for green spears in open field technology in the Central Poland. Proceedings of the $19^{\text {th }}$ International Scientific Conference "Economic Science for Rural Development 2018", Latvia, Jelgava, May 9-11, 2018, pp. 71-76.

[9] Stachowski P., Markiewicz J. The need of irrigation in central Poland on the example of Kutno country. Annual Set of Environment Protection, vol. 13, 2011, pp. 1453-1472.

[10] Grabarczyk S., Żarski J., Dudek S. Sterowanie deszczowaniem według opadów atmosferycznych. Roczniki Akademii Rolniczej w Poznaniu, vol. CCXXXIV, 1992, pp. 83-90. (In Polish)

[11] Mc Kee T.B., Doesken N.J., Kleist J. The relationship of drought frequency and duration to time scales. Proceedings of $8^{\text {th }}$ Conference on Applied Climatology, January 17-22, 1993, Anaheim, CA, pp. 179-184.

[12] Grabarczyk S. Profitability of the sprinkler irrigation investments in private peasant farms. Zeszyty Problemowe Postępów Nauk Rolniczych, vol. 326, 1987, pp. 449-456.

[13] Łuszczyk K. Nakłady na nawadniane plantacje ziemniaków. Maszynopis. Łukomet, Całowanie, 2008, pp. 1-10. (In Polish)

[14] Łuszczyk K. Nakłady na nawadnianie plantacji roślin towarowych. Infrastructure and Ecology of Rural Areas, vol. 6, 2009, pp. 303-315. (In Polish)

[15] Nowak L. Efekty deszczowania ziemniaków średnio wczesnych w rejonie Wrocławia zależnie od ilości opadów. Fragmenta Agronomica, vol. 1, 2001, pp. 69-75. (In Polish)

[16] Chmura K., Rojek S. Irrigating potatoes in the Wrocław region. Przegląd Naukowy Wydziału Inżynierii i Kształtowania Srodowiska SGGW, vol. 22, 2001, pp. 259-274.

[17] Rutkowski M., Małecka I. Economic efficiency of sprinkler irrigation of some crops. Zeszyty Problemowe Postępów Nauk Rolniczych, vol. 268, 1986, pp. 535-540.

[18]Rutkowski M. Profitability of the sprinkler irrigation of agricultural and horticultural crops. Zeszyty Problemowe Postępów Nauk Rolniczych, vol. 326, 1987, pp. 167-198.

[19] Rolbiecki S., Rzekanowski C., Żarski J., Rolbiecki R. Cost-effectiveness of overhead irrigation of vegetables cultivated in the vicinity of Bydgoszcz. Zeszyty Naukowe ATR Bydgoszcz, vol. Rolnictwo 44, 1999, pp. 251-256.

[20]Żarski J., Rzekanowski C., Dudek S., Rolbiecki S. Cost-effectiveness of overhead irrigation of field crops cultivated in the vicinity of Bydgoszcz. Zeszyty Naukowe ATR Bydgoszcz, vol. Rolnictwo 44, 1999, pp. 315-320.

[21] Żarski J., Rolbiecki S., Rzekanowski C., Rolbiecki R., Dudek S., Grzelak B. Cost-effectiveness of sprinkler irrigation of field crops and vegetables in central Poland. Przegląd Naukowy Wydziału Inżynierii i Kształtowania Środowiska SGGW, vol. 22, 2001, pp. 375-382.

[22] Kuchar L., Iwański S. Rainfall simulation for the prediction of crop irrigation in future climate. Infrastructure and Ecology of Rural Areas, vol. 5, 2011, pp. 7-18.

[23] Kuchar L., Iwański S. Rainfall evaluation for crop production until 2050-2060 and selected climate change scenarios for North Central Poland. Infrastructure and Ecology of Rural Areas, vol. 2(I), 2013, pp. 187-200.

[24] Kuchar L., Iwański S., Diakowska E., Gąsiorek E. Simulation of hydrothermal conditions for crop production purpose until 2050-2060 and selected climate change scenarios for North Central Poland. Infrastructure and Ecology of Rural Areas, vol. II(1), 2015, pp. 319-334.

[25] Kuchar L., Iwański S., Diakowska E., Gąsiorek E. Assessment of meteorological drought in 2015 for North Central part of Poland using hydrothermal coefficient (HTC) in the context of climate change. Infrastructure and Ecology of Rural Areas, vol. I(2), 2017, pp. 257-273.

[26] Łabędzki L. Foreseen climate changes and irrigation development in Poland. Infrastructure and Ecology of Rural Areas, vol. 3, 2009, pp. 7-18.

[27] Łabędzki L., Bąk B., Liszewska M. Wpływ przewidywanej zmiany klimatu na zapotrzebowanie ziemniaka późnego na wodę. Infrastructure and Ecology of Rural Areas, vol. 2(I), 2013, pp. 155165. (In Polish)

[28]Żarski J., Dudek S., Kuśmierek-Tomaszewska R., Rolbiecki R., Rolbiecki S. Forecasting effects of plant irrigation based on selected meteorological and agricultural drought indices. Annual Set The Environment Protection, vol. 15, 2013, pp. 2185-2203. 
[29] Rolbiecki S., Rolbiecki R., Dudek S., Kuśmierek-Tomaszewska R., Żarski J., Rzekanowski C. Requirements and effects of drip irrigation of mid-early potato on a very light soil in moderate climate. Fresenius Environmental Bulletin, vol. 24(11b), 2015, pp. 1-8.

[30] Kledzik R., Kropkowski M., Dudek S., Kuśmierek-Tomaszewska R., Żarski J. Evaluation of economic efficiency of irrigation in corn for grain production in 2005-2016. Infrastructure and Ecology of Rural Areas, vol. II(1), 2017, pp. 587-598.

[31] Wszelaczyńska E., Pobereżny J., Dudek S., Kuśmierek-Tomaszewska R., Żarski J., Pawelzik E. The effects of fertilizers, irrigation and storage on the properties of potato tubers and their constituent starches. Starch/Stärke, 67, 2015, pp. 478-492.

[32]Rolbiecki S., Rolbiecki R., Rzekanowski Cz, Wojdyła T. Effect of sprinkler irrigation and nitrogen fertilization on technological and storage value of chosen potato cultivars. Acta Horticulturae, 729, 2007, pp. 353-356. 